not violated. The theory only takes into account macrostresses. Problems associated with pseudo-macrostresses cannot be solved using my theory but neither can the methods advocated above by Noyan \& Cohen as Noyan (1983) admits. Kossel techniques should be used in order to get more insight into these stresses.

The separation of macro- and pseudomacrostresses (by definition varying from grain to grain) as suggested by Noyan (1983) seems impossible in most cases with reference to the present 'state of the art'. If the orientation dependency of the pseudo-macrostresses (Noyan, 1983) is neglected this is possible but then, strictly speaking, these stresses are treated as macrostresses.

(ii) For multi-phase materials the texture contribution to the $\psi$ splitting and/or non-linearities can be subtracted' using my equations if one or more phases exhibit any significant texture.

(iii) Oscillations in experimentally obtained $\left\langle\varepsilon_{z z}^{\prime}\right\rangle v s \sin ^{2} \psi$ data need not indicate the presence of an inhomogeneous strain state but can also be a result of crystallographic texture (Noyan \& Cohen, 1983)

\section{M. BRAKMAN}

\author{
Laboratory of Metallurgy \\ Delft University of Technology \\ Rotterdamseweg 137 \\ 2628 AL Delft \\ The Netherlands
}

(Received 4 November 1983; accepted 18 January 1984)

\section{References}

Brakman, C. M. (1983). J. Appl. Cryst. 16. 325-340.

Hashimoto, K. \& Margolin, H. (1983). Acta Metall. 31, 787-800.

Hauk, V., Oudelhoven, R. \& Vaessen, G (1981). Haerterei-Tech. Mitt. 36, 258-261.

Hirsch, J., Virnich, K. H. \& Lücke, K. (1981). Textures of Materials. Proc. Sixth International Conference on Textures of Materials, pp. 375-384.

Kneer, G. (1965). Phys. Status Solidi, 9 , 825-838.

Kröner, E. (1958). Z. Phys. 151, 504-518.

Kröner, E. (1967). J. Mech. Phys. Solids; 15, 319-329.

Morris, P. R. (1970). Int. J. Eng. Sci. 8 , 49-61.

Naumann, R. (1982). Haerterei Tech. Mitt. Beiheft, pp. 106-112.

Noyan, I. C. (1983). Metall. Trans. A, 14A, 1907-1914.
Noyan, I. C. \& Cohen, J. B. (1983). Denver $X$-ray Conference, Vol. 32 . In the press.

Ridha, A. A. \& Hutchinson, B. (1981). Textures of Materials. Proc. Sixth International Conference on Textures of Materials, pp. 112-131.

Timoshenko, S. P. \& Goodier, J. N. (1970) Theory of Elasticity, p. 236. New York: McGraw-Hill, International Student Edition.

Wakabayashi, M., Nakayama, M. \& Nagata, A. (1977). J. Jpn. Precis. Eng. 43, 661-667.

Editorial comment: The authors of these two letters still do not agree on the conclusions. The technical situation is complicated, mainly due, it appears, to misunderstandings generated by imprecise terminology and incomplete mathematical models. The dialogue published here will, I hope, generate continued discussion leading to new science and better insights.

Correspondence is closed; original papers within the scope of the Journal of Applied Crystallography are welcomed.

M. HART

\section{Crystallographers}

J. Appl. Cryst. (1983). 16, 217

This section is intended to be a series of short paragraphs dealing with the activities of crystallog raphers, such as their changes of position, promotions, assumption of significant new duties, honours, etc. Items for inclusion. subject to the approval of the Editorial Board, should be sent to the Executive Secretary of the International Union of Crystallography (J.N. King, International Union of Crystallography. 5 Abbey Square, Chester $\mathrm{CH} 12 \mathrm{HU}$. England).

Professor Sixten Abrahamsson died on 13 January 1984, the day before his 54th birthday. Professor P. Kierkegaard writes that Abrahamsson was born in the province of Darlecarlia in Sweden. His university education was at Uppsala, where he received his doctor's degree in chemistry in 1959. In the same year he became docent in general and inorganic chemistry. He had started his research as a student of Professor Gunnar Hägg. who at that time had widened the scope of the crystallographic research at his Institute into the field of structures of inorganic molecules of biochemical interest. This was done in close cooperation with Professor Einar Stenhagen; and Abrahamsson's thesis, which concerned long branched-chain fatty acids, was an important part of that cooperation. One year's stay with Professor Dorothy Hodgkin at Oxford was of great importance for his development as a scientist. In 1960 Abrahamsson followed Stenhagen, who a few years earlier had moved from Uppsala to Gothenburg, and in 1966 Abrahamsson was appointed by the Medical Research Council at the Faculty of Medicine of the University of Gothenburg to a personal chair in organic molecular structure research. In that position Abrahamsson was able to develop a small but very successful research group. Their work comprised structure-function studies of molecules with biological activity, with particular emphasis during the last years on the type of lipids found in biological membranes. Abrahamsson took a great interest in instrumentation and the use of computers as aids in crystallographic research. The development of his film scanner, described in 1966, was pioneer work in fast and accurate X-ray data collection. His competence in the field of computers was also widely utilized in areas outside science, particularly for hospitals and other medical applications. As a member of the IUCr's Commission on Crystallographic Computing from 1969 until 1975 and of the Commission on Crystallographic Apparatus from 1975 (its chairman from 1978), he initiated and substantially contributed to several projects of both Commissions. Sixten Abrahamsson was personally confident, helpful and a faithful friend, and he will be mourned and remembered by many friends, colleagues and students in Sweden and abroad.

George W. Brindley, Professor Emeritus of Mineral Sciences at the Pennsylvania State University, University Park. Pennsylvania died 23 October 1983 at the age of 78 . He began his X-ray studies with the Bragg school at Manchester University, England, where he received an MSc in 1928. Leeds University awarded him a $\mathrm{PhD}$ in 1933. Professor R. E. Newnham writes that G.W. Brindley held various posts in the physics department at Leeds, becoming Reader in X-ray Physics in 1948. His research interests, until about 1945, were mainly in the scattering of $X$-rays by atoms and in metal line broadening caused by mechanical deformation and thermal vibration. James and Brindley scattering factors were used by crystallographers throughout the world for more than twenty years. Shortly after World War II, he took up the study of clay minerals and achieved an international reputation for his work on the structures of kaolinite, dickite, halloysite, serpentine, and chlorite. Later, he investigated the phase transformations in clays caused by thermal and chemical treatment and, more recently, the structural aspects of 
clay-organic complexes. The mineral Brindleyite, a nickel-bearing clay, was named in his honor by colleagues in Yugoslavia. He moved to the USA in 1953 , serving as a research professor of mineral sciences at Penn State until 1955 when he became chairman of the Department of Ceramic Technology. In 1962, he was named Professor of Mineral Sciences and served in that capacity until his retirement in 1973. In 1970, the Mineralogical Society of America awarded him the Roebling Medal for his work on clay minerals. He was past president and distinguished member of the Clay Minerals Society, fellow of the American Ceramic Society, and an honorary member both of the French Society of Mineralogy and Crystallography and the Mineralogical Society of London. George Brindley wrote more than 300 research papers, including two editions of the book Crystal Structures of Clay Minerals and Their $X$-ray Identification.

Professor T. L. Blundell, Professor of Crystallography at Birkbeck College, London, Professor J. B. Pendry, Professor of Theoretical Solid State Physics at Imperial College, London, and Professor M. M. Woolfson, Professor of Physics in the University of York, have been elected as Fellows of the Royal Society.

Professor David Harker has been awarded the 1984 Gregory Aminoff gold medal and prize by the Royal Swedish Academy of Sciences for his fundamental contributions to the development of methods in X-ray crystallography. This is the fifth time that the Aminoff prize has been awarded. The first recipient being Professor P. P. Ewald in 1979, the second Sir Charles Frank in 1981 and the third and fourth to Professors G. Hägg in 1982 and J. M. Robertson in 1983.

Professor D. W. Smits, of the University Computer Centre, Groningen, The Netherlands, recently received the high, Royal Distinction of being appointed an Officer in the Order of Orange-Nassau on the occasion of his retirement as Director of the Computing Centre which he helped to create in 1964, and in recognition of his services to computing in The Netherlands and his participation in international scientific affairs. Professor Smits was General Secretary of the International Union of Crystallography from 1954 until 1966.

\section{International Union of Crystallography}

\author{
J. Appl. Cryst. (1984) 17, 218
}

\section{Commission on Journals Changes in Editorial Boards}

There have been several recent changes in the Editorial Boards of the IUCr journals and there will be further changes later in 1984.

Professor G. A. Jeffrey completed his term of office in September 1983 and Protessor D. H. Templeton has resigned on his election as President of the American Crystallographic Association. Their successors are Professor C. E. Bugg. Professor James A. Ibers, Professor C. E. Nordman and Professor H. Steinfink. In addition, Professors J. Drenth and C. E. Bugg have been appointed as Netherlands and US Co-editors of Acta Crystallographica.

Professor M. Hart and Dr F. R. Ahmed complete their terms of office as Editor of Journal of Applied Crystallography and Co-editor of Acta Crystallographica, respectively, at the XIllth Congress of Crystallography. The names of their successors will be announced in due course. 